\title{
Allelic variation of Mhc class II in Atlantic salmon; a population genetic analysis
}

\author{
ÅSA LANGEFORS $* \dagger$, TORBJ ÖRN VON SCHANTZ $\uparrow \&$ BENGT WIDEGREN $\ddagger$ \\ $\dagger$ Department of Animal Ecology, Ecology Building, Lund University, 22362 Lund, Sweden and †Department of \\ Tumour Immunology, Institute of Cell and Molecular Biology, The Wallenberg Laboratory, Sölvegatan 33, S-223 62 \\ Lund, Sweden
}

\begin{abstract}
We have studied the degree of genetic variation at a variable Mhc class II $\beta$ gene in four populations of Atlantic salmon Salmo salar by using RFLPs. The class II $\beta$ gene encodes the part of the Mhc class II molecule that contains the antigen binding region and is therefore essential for disease resistance. There was extensive genetic variation in all four populations; the expected heterozygosity $\left(H_{\mathrm{S} i}\right)$ varied between 0.50 and 0.81 . Heterozygosity tended to be higher in broods surviving a syndrome causing high mortalities (60-95\%) in Swedish salmon hatcheries. Populations that had experienced more incidences of genetic bottlenecks (years when fewer than 60 adults had been used for breeding) and had a lower average effective population size $\left(N_{\mathrm{e}}\right)$, had a lower degree of heterozygosity. The four populations differed significantly in allele frequencies as measured by $F_{\mathrm{ST}}=0.13$ and Nei's genetic distance $(D=0.09-\infty)$. Pairwise $F_{\mathrm{ST}}$ values varied between 0.01 and 0.23 , all but one being highly significant, indicating a differentiation between the populations in $M h c$ class II $\beta$. This study shows that the four populations of Atlantic salmon have a high degree of polymorphism in the $M h c$ class II $\beta$ gene. However, there was great variation between different hatcheries, both in heterozygosity levels and allele frequencies.
\end{abstract}

Keywords: allele frequency, Atlantic salmon, genetic variation, heterozygosity, Mhc, population.

\section{Introduction}

In Sweden, Atlantic salmon have been cultured since the 1950s to compensate for the loss of natural spawning sites caused by dams (Eriksson \& Eriksson, 1993). Each season only between 0.1 and $1 \%$ of the returning mature salmon are used for breeding in the hatcheries. Thus, the effective population sizes $\left(N_{\mathrm{e}}\right)$ of the managed populations have probably been only a small fraction of the $N_{\mathrm{e}}$ of natural populations. Because of the low number of breeders in the hatcheries, the managed populations have been exposed to repeated genetic bottlenecks which decrease the genetic variation, in particular allelic diversity and also levels of heterozygosity, which increases the risk of inbreeding depression. Studies of hatchery populations of salmon indicate that the degree of heterozygosity may be reduced because of genetic drift from a small number of founders (Allendorf \& Phelps, 1980) or be increased because of the mixing of breeders from different populations (Guyomard \& Krieg, 1983). Ryman \& Ståhl (1980) stated that by using 30 breeding pairs $\left(N_{\mathrm{e}} \approx 60\right)$, sufficient genetic variation should be maintained in Atlantic salmon populations. In addition, Nyman \& Norman (1987) suggested the use of 25 pairs $\left(N_{\mathrm{e}}=50\right)$ to keep inbreeding at $\leq 1 \%$ per generation.

When studying cultured salmon populations potentially vulnerable to diseases, it is of special interest to investigate genes that can mediate disease resistance. A reduction in the degree of variation in such genes may have a particularly adverse effect on viability (Allendorf \& Phelps, 1980). In mammals and birds $M h c$ genes encode cell surface molecules that recognize and bind foreign peptides (antigens), derived mainly from pathogens (e.g. viruses, bacteria and protozoa) and present these to T-cells, which then initiate the immune response (Klein, 1990). Similar pathways are believed to occur also in fish (Miller et al., 1993). In humans, mice and chickens, there are two main classes of polymorphic $M h c$ genes, class I and class II, each consisting of two or more loci (Klein, 1990). Mhc genes show extreme 
allele variation (Klein, 1990) and it has been suggested that individuals heterozygous at $M h c$ are at a selective advantage (Hughes \& Nei, 1988). In mammals, there are only a few studies of $M h c$ polymorphism in wild populations and the results are contradictory. In different studies, both extensive (Nizetic et al., 1985) and a surprisingly low degree of Mhc gene variation (Ellegren et al., 1994) have been found. In fish, such studies are based on very few individuals and the results are as contradictory as they are in mammals (Grimholt et al., 1994; Hardee et al., 1995).

Our purpose in the present study was to investigate the amount of variation in the Mhc class II $\beta$ gene in managed populations of Atlantic salmon. Using RFLP, we screened juvenile salmon from four different hatcheries located at rivers along the Swedish Baltic Sea coast. The four hatchery populations differ in the numbers of adults used each year for breeding and we therefore investigated whether the smaller populations had lower $M h c$ variation than populations with larger average population sizes. We also studied the degree of genetic differentiation between the four populations in relation to geographical distance. As a reference group, we used 25 wild-caught, naturally produced juveniles from the Kochovka River in north-western Russia.

\section{Materials and methods}

\section{Study populations}

Culturing of Atlantic salmon in Sweden is a means to compensate for the loss of natural reproduction caused by the damming of rivers. At the hatcheries, mature, wild adults are caught in their natal rivers and sperm from one male is mixed with the eggs from one female and fertilization takes place in a bucket. Juveniles are given sufficient food supply and are provided with medication, e.g. antibiotics, when showing any disease symptoms. At the age of 2 years, the juveniles are released into the river where they continue to grow and subsequently migrate to the sea.

Newly hatched salmon were collected from hatcheries located at four rivers along the Swedish Baltic Sea coast, from south to north: Mörumsån, $56^{\circ} 12^{\prime} \mathrm{N}, 14^{\circ} 44^{\prime} \mathrm{E}$, in 1993 ; Dalälven, $60^{\circ} 34^{\prime} \mathrm{N}$, $17^{\circ} 29^{\prime} \mathrm{E}$ and Umeälven, $63^{\circ} 51^{\prime} \mathrm{N}, 20^{\circ} 5^{\prime} \mathrm{E}$, in 1994 ; and Luleälven, $65^{\circ} 51^{\prime} \mathrm{N}, 21^{\circ} 30^{\prime} \mathrm{E}$, in 1995 . In Umeälven and Dalälven, each female is fertilized by one male, giving full-sib broods, whereas more than one male may fertilize each female in the other two populations, giving half-sib broods. However, because we used only one, randomly selected individual from each brood, variation in relatedness within broods does not bias our results.

During the early 1990s; Swedish hatcheries on the Baltic Sea suffered a great loss of salmon broods caused by a syndrome called M74. A major symptom of M74 is that all individuals within a brood die during the yolk-sac stage, a couple of weeks after hatching, soon before they start to feed by themselves. What causes M74 is not known, though there are indications of increased detoxification activities (Bengtsson et al., 1994), decreased nutrition levels (carotenoids, Lignell, 1995; vitamin $\mathrm{B}_{1}$, Amcoff et al., 1995) and a low degree of genetic variation $(\AA$. Langefors, T. von Schantz and B. Widegren, unpublished observation). We collected juveniles both from broods dying from M74 and surviving broods aiming at keeping the proportions of these two groups as equal as possible. The losses of broods from M74 in the studied hatcheries were (proportions of M74-broods in our samples in parentheses) 0.58 (0.25) in River Luleälven, 0.70 (0.61) in Dalälven, $>0.90$ (0.62) in Umeälven, and 0.95 (0.77) in Mörrumsån. Prior to 1993, M74 occurred at low levels in the Baltic Sea salmon populations. The parents of the studied broods were hatched before 1993 and therefore were probably only to a minor extent affected by selection by M74.

As a reference population, 25 salmon juveniles were collected from the Kochovka River, $67^{\circ} 24^{\prime} \mathrm{N}$, $41^{\circ} 1^{\prime} \mathrm{E}$, at the Kola peninsula in 1994 . To our knowledge, the Kochovka River has not been exposed to any form of culturing. This population is isolated from the Baltic Sea and it has no genetic exchange with the four study populations.

\section{Population sizes}

Information on numbers of breeders used for breeding is available for the hatcheries in Umeälven \& Luleälven for 1965-93 (Laxforskningsinstitutet, Sweden), from Dalälven for 1973-93 (1973-81, H. Börjesson, pers. comm., 1982-93, Laxforskningsinstitutet, Sweden) and from Mörrumsån for 1979-92 (S. E. Harrysson, pers. comm.). For each population, $N_{\text {ei}}$, the effective population size allowing for sex-ratio biases in year $i$ was calculated as:

$N_{\mathrm{e} i}=4 N_{\mathrm{m} i} N_{\mathrm{fi} i} /\left(N_{\mathrm{m} i}+N_{\mathrm{fi}}\right)$,

where $N_{\mathrm{m} i}$ and $N_{\mathrm{fi}}$ are the numbers of males and females used for breeding in year $i$. The average $N_{\mathrm{e}}$ over all years was calculated as the harmonic mean of the $N_{\mathrm{e} i}$. The age-distribution of salmon populations can affect the effective population size 
Table 1 Average effective population size $\left(N_{\mathrm{e}}\right)$, and number of years with genetic bottlenecks $\left(N_{\mathrm{e} i}<60\right)$ between 1965 and 1993, as well as for the given years, expected $\left(H_{\mathrm{S} i}\right)$ and observed $\left(H_{\mathrm{I} i}\right)$ heterozygosities, results of binomial tests $(d), F_{\mathrm{IS}}$, number of observed alleles and sample size $(n)$ in each of four Baltic Sea hatchery populations of Atlantic salmon, and in a reference population from the Kochovka River

\begin{tabular}{|c|c|c|c|c|c|c|c|c|}
\hline Population & $N_{\mathrm{e}}$ & $\begin{array}{c}\text { Years with } \\
N_{\mathrm{e} i}<60\end{array}$ & $H_{\mathrm{S} i}{ }^{1}$ & $H_{\mathrm{I} i}{ }^{1}$ & $d$ & $F_{\text {IS }}$ & No. alleles & $n$ \\
\hline Luleälven-95 & 394 & 0 & $0.81 b$ & $0.86 b$ & $0.82 \mathrm{NS}$ & $-0.07 \mathrm{NS}$ & 14 & 36 \\
\hline Umeälven-94 & 68 & 9 & $0.50 a$ & $0.42 a$ & $-1.03 \mathrm{NS}$ & $0.16 \mathrm{NS}$ & 8 & 26 \\
\hline Dalälven-94³ & 116 & 0 & $0.81 b$ & $0.83 b$ & $0.28 \mathrm{NS}$ & $-0.02 \mathrm{NS}$ & 16 & 41 \\
\hline Mörrumsån-934 & 35 & 11 & $0.63 a b$ & $0.69 a b$ & $0.46 \mathrm{NS}$ & $-0.10 \mathrm{NS}$ & 8 & 13 \\
\hline Kochovka River-94 & & & $0.69 a b$ & $0.68 a b$ & $-0.10 \mathrm{NS}$ & $0.01 \mathrm{NS}$ & 7 & 25 \\
\hline
\end{tabular}

${ }^{1}$ Populations marked with different letters ( $a$ or $b$ ) differ significantly at the $5 \%$ level in heterozygosity. Populations sharing a letter $(a$ or $b)$ do not differ significantly in heterozygosity.

${ }^{3} N_{\mathrm{e}}$ and years with $N_{\mathrm{e} i}<60$ based on the period 1973-93.

${ }^{4} N_{\mathrm{e}}$ and years with $N_{\mathrm{e} i}<60$ based on the period 1979-92.

(Waples, 1990). However, we have no data on the age-distributions in our study populations. Effective population size and number of genetic bottlenecks (years when $N_{\mathrm{e}}<60$ ) are presented in Table 1.

\section{RFLP analysis}

Phenol-chloroform extracted DNA samples of $20 \mu \mathrm{g}$ were digested with the restriction enzyme RsaI and electrophoresed in a 1.0\% agarose gel in TBE buffer on $50 \mathrm{~V}$ for $17 \mathrm{~h}$. Following denaturation and neutralization, the DNA was transferred to a nylon membrane (Magna, MSI, Westboro, MA 01581, USA) and UV-crosslinked. The membranes were prehybridized at $62^{\circ} \mathrm{C}$ for $45 \mathrm{~min}$ in $0.5 \mathrm{M} \mathrm{Na}_{2} \mathrm{HPO}_{4}$, $1 \%$ SDS and hybridized with ${ }^{32} \mathrm{P}$-labelled Sasa II probe (a $1.4 \mathrm{~kb}$ cDNA probe consisting of exon 1 to the $3^{\prime}$ UT region of the $M h c$ class II $\beta$ of Atlantic salmon, with six $R s a$ I sites, Hordvik et al., 1993) at $62^{\circ} \mathrm{C}$ overnight. Membranes were washed at $62^{\circ} \mathrm{C}$, for $20 \mathrm{~min}$ in $2 \times \mathrm{SSC}$ and $0.5 \times \mathrm{SSPE}, 30 \mathrm{~min}$ in $1 \times \mathrm{SSC}$ and $0.5 \times \mathrm{SSPE}, 30 \mathrm{~min}$ in $0.5 \times \mathrm{SSC}$ and $0.5 \times$ SSPE. The hybridized filters were exposed to $\mathrm{X}$-ray film for 7-14 days.

When hybridizing with probes consisting of only intron one or exon two of the class II $\beta$ gene, only one (homozygous individuals) or two (heterozygous individuals) bands were present. These results together with PCR and sequencing analysis point to the existence of one single MHC class II $\beta$ locus in Atlantic salmon ( $\AA$. Langefors and T. von Schantz, unpubl. obs.).

The RFLP bands visible when hybridizing with the Sasa II probe were in the size range of $\sim 500-3000$ bp (Fig. 1). Individuals were classified as homozygous genotypes when having two RFLP bands, and as heterozygotes when having three or four RFLP bands. Homozygous genotypes had more intense bands than heterozygous genotypes with four bands. Genotypes with three bands had one strong band and two weaker bands; thus, some genotypes share one band or alternatively contain two bands indistinguishable from each other (Fig. 1).

\section{Data analysis}

If no selection has occurred and mating is random, the frequency of heterozygous individuals will agree with the Hardy-Weinberg equilibrium. Therefore, observed $\left(H_{\mathrm{I}}\right.$, number of observed heterozygous individuals) and expected $\left(H_{\mathrm{S} i}\right.$, calculated according to Nei, 1978) heterozygosities were tested against a binomial distribution and by calculating $F_{\mathrm{IS} i}$ (deviation from Hardy-Weinberg proportions within the $i$ th population, Nei, 1977) in each population (both before and after M74 selection) as:

$F_{\mathrm{IS} i}=\left(H_{\mathrm{S} i}-H_{\mathrm{I} i}\right) / H_{\mathrm{S} i}$.

All observed genotypes were included in the tests. Interpopulation variation in allele frequency distribution, $F_{\mathrm{ST}}$ (genetic differentiation of populations), was calculated according to Nei (1977):

$F_{\mathrm{ST}}=\left(H_{\mathrm{T}}-H_{\mathrm{S}}\right) / H_{\mathrm{T}}$,

where $H_{\mathrm{T}}$ is the expected heterozygosity in the total data set and $H_{\mathrm{S}}$ is the average expected heterozygosity in the populations. $F_{\text {ST }}$ was tested for normal distribution using $\operatorname{Var}\left(F_{\mathrm{ST}}\right)$ as obtained using the jackknife procedure described by Weir \& Cockerham (1984) and by $\chi^{2}=2 N F_{\mathrm{ST}}$, where $N$ is the 
number of individuals and degrees of freedom are the number of populations minus one (Hedrick, 1985). The jackknife procedure was performed by repeated $F_{\text {ST }}$ calculations excluding one population in each calculation to obtain a mean value and a variance (Weir \& Cockerham, 1984). Nei's genetic distance was calculated following Hartl \& Clark (1989). Differences in the frequencies of each allele were tested using Fisher's exact test with sequential Bonferroni-corrected significance levels.

The levels of heterozygosity $\left(H_{\mathrm{S} i}\right.$ and $\left.H_{\mathrm{I} i}\right)$ between populations were compared and tested by chi-squared tests both before and after M74 selection (Tables 1 and 2). In tests on surviving broods,

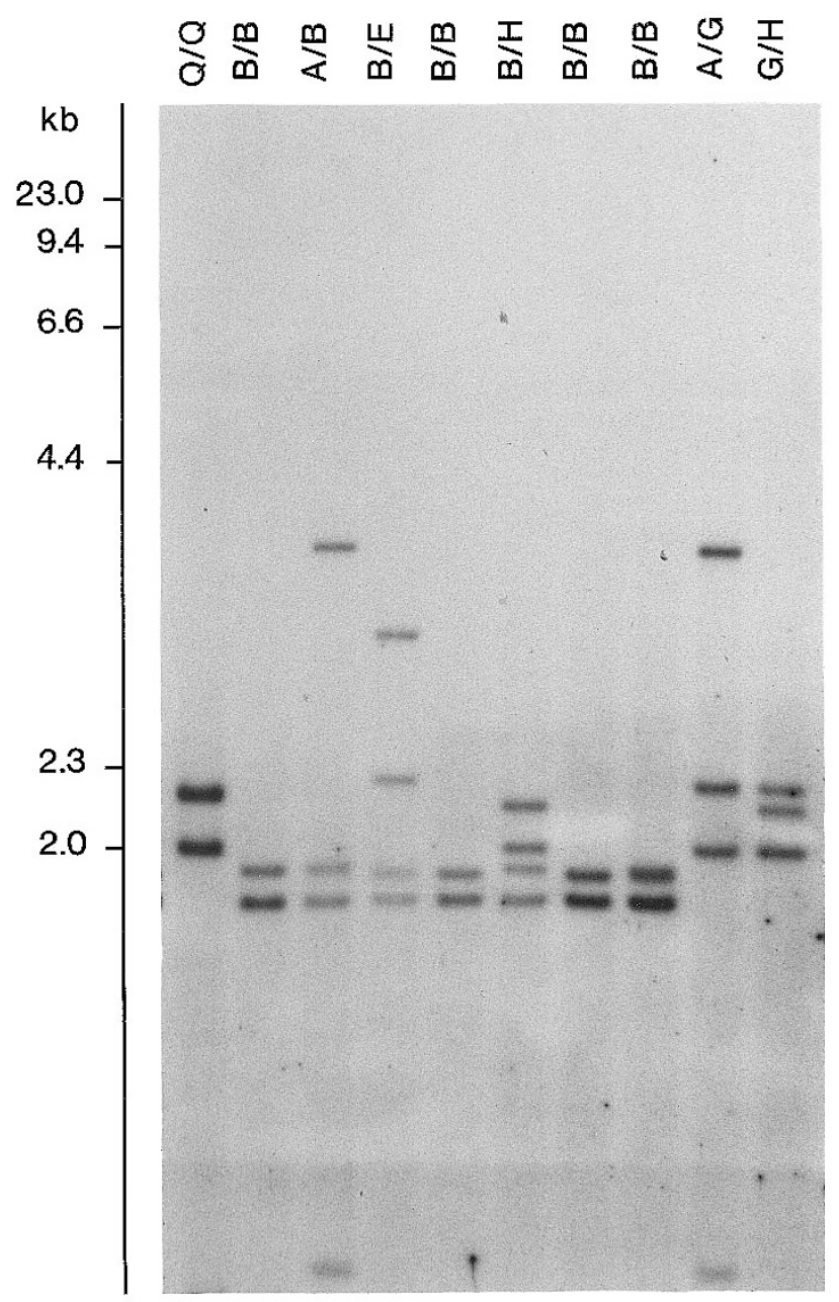

Fig. 1 One genotype from Mörrumsån (lane 1) and nine from Umeälven (lanes 2-10) showing six of the 24 identified alleles (each allele $=2$ RFLP bands) defined by $R s a \mathrm{I}$ and a $M h c$ class II $\beta$ cDNA probe from Atlantic salmon. Note that alleles $G$ and $H$ share one band, hence only three bands are present in genotype $G / H$ (see Materials and methods).
Table 2 Heterozygosity levels and $F_{\text {IS }}$ in broods of Atlantic salmon that have survived M74. Symbols as in Table 1

\begin{tabular}{lccccr}
\hline Population & $H_{\mathrm{S} i}{ }^{1}$ & $H_{\mathrm{I} i}{ }^{1}$ & $d$ & $F_{\mathrm{IS}}$ & $n$ \\
\hline Luleälven-95 & $0.82 b$ & $0.89 b$ & $0.99 \mathrm{NS}$ & $-0.09 \mathrm{NS}$ & 27 \\
Umeälven-94 & $0.55 a$ & $0.60 a$ & $0.32 \mathrm{NS}$ & $-0.09 \mathrm{NS}$ & 10 \\
Dalälven-94 & $0.75 a b$ & $0.94 b$ & $1.72 \mathrm{NS}$ & $-0.25 \mathrm{NS}$ & 16 \\
Mörrumsån-93 & $0.69 a b$ & $1.00 a b$ & $1.15 \mathrm{NS}$ & $-0.44 \mathrm{NS}$ & 3 \\
\hline
\end{tabular}

we used Yate's correction for small sample sizes for the data from Mörrumsån (Table 2).

\section{Results}

We identified $23 M h c$ class II $\beta$ alleles in the four hatchery populations and one additional allele in the wild, North Atlantic population (see Appendix). Three of the 23 alleles showed significant differences in frequencies between populations $(B, E$, and $Q$; Appendix). Umeälven had one very frequent allele $(B, 0.69)$ and seven alleles with frequencies below 0.10 (see Appendix). Mörrumsån had one frequent allele $(Q, 0.58)$, a second common allele $(L, 0.15)$ and six alleles with frequencies below 0.10 . Luleälven had the most even allele distribution; allele $B$ had a frequency of 0.33 , alleles $C, D$ and $E$ had frequencies of $0.10-0.21$ and 10 other alleles had frequencies below 0.10. Dalälven had two common alleles $(B, 0.35$ and $E, 0.21)$ and 14 alleles with a frequency of $<0.10$ (see Appendix). There was a large variation between populations in the number of rare alleles (i.e. alleles with frequencies of $\leq 0.05$ ), ranging from four (Umeälven) to 12 (Dalälven). No particular allele seemed to give any selective advantage in relation to M74 (see Appendix).

Salmon in the Rivers Dalälven $\left(H_{\mathrm{S} i}=0.81\right)$ and Luleälven $\left(H_{\mathrm{S} i}=0.81\right)$ had higher $M h c$ heterozygosity levels than in Umeälven $\left(H_{\mathrm{S} i}=0.50, P<0.05\right.$, Table 1). The salmon in Mörrumsån had an intermediate level of $H_{S i}(0.63)$ which did not differ significantly from any of the other populations (Table 1). Observed heterozygosity did not differ from expected Hardy-Weinberg proportions (Table 1).

The surviving broods in all populations tended to have an excess of heterozygous individuals $\left(H_{\mathrm{Ii}}>H_{\mathrm{S}}\right.$, Table 2). Expected heterozygosity $\left(H_{\mathrm{S} i}\right)$ differed between Umeälven and Luleälven $(P<0.05$, Table 2$)$ and the observed heterozygosity $\left(H_{\mathrm{I} i}\right)$ in Umeälven differed from values in Luleälven and Dalälven $(P<0.05$, Table 2$)$. In all populations, $F_{\mathrm{IS} i}$ decreased after the selection pressure of $\mathrm{M} 74$, indicating a 
tendency for selection against homozygotes during exposure to the M74 syndrome. However, observed heterozygosity levels were not statistically different from the levels in the total samples $(P>0.05$, based on data presented in Tables 1 and 2).

There were large variations in allele abundance and allele frequencies between the hatchery populations $\quad\left(F_{\mathrm{ST}}=0.13, \quad \chi_{3}^{2}=30.17, \quad P<0.001 ;\right.$ jackknife procedure $\left.\operatorname{Var}\left(F_{\mathrm{ST}}\right)=0.0064, d=3.260, P<0.001\right)$. No allele was shared between salmon of Umeälven and Mörrumsån, hence a genetic distance of infinity (Table 3). The shortest genetic distance was found between Luleälven and Dalälven $(D=0.085$, Table 3).

\section{Discussion}

This study is unique in that it deals with genetic variation in different salmon populations using an Mhc class II $\beta$ gene as the genetic marker. A large array of studies have been performed on genetic variation in salmonid populations. The great majority of these studies are based on allozyme electrophoreses (Guyomard, 1981; Ståhl, 1981) although studies on mtDNA and microsatellites have also recently been performed (e.g. Bernatchez et al., 1992; Tessier et al., 1995). We found extensive variation in the $M h c$ class II $\beta$ within and between the four populations of Atlantic salmon. We used the RFLP technique to study $M h c$ variation, and even though it does not detect all nucleotide diversity, it appears to be a good predictor of $M h c$ variation (Mikko \& Andersson, 1995) and it facilitates screening of large numbers of individuals.

Table 3 Nei's genetic distance ( $D$, bold script, below diagonal) and pairwise $F_{\text {ST }}$ values (normal script, above diagonal) between four hatchery populations of Atlantic salmon and one reference population from the Kochovka River

\begin{tabular}{lccccc}
\hline & \multicolumn{5}{c}{ Population } \\
\cline { 2 - 6 } Population & Lul & Ume & Dal & \multirow{2}{*}{ Mör } & \multirow{2}{*}{ Koch } \\
\hline Lul & & $0.096^{* *}$ & $0.010 \mathrm{NS}$ & $0.172^{* * *}$ & $0.119^{* * *}$ \\
Ume & $\mathbf{0 . 2 0 8}$ & & $0.101^{* * *}$ & $0.232^{* * *}$ & $0.235^{* * *}$ \\
Dal & $\mathbf{0 . 0 8 5}$ & $\mathbf{0 . 1 6 9}$ & & $0.162^{* * *}$ & $0.133^{* * *}$ \\
Mör & $\mathbf{3 . 9 1 3}$ & $\infty$ & $\mathbf{2 . 2 5 4}$ & & $0.196^{* * *}$ \\
Koch & $\mathbf{1 . 3 3}$ & $\mathbf{2 . 5 2 1}$ & $\mathbf{1 . 9 2 8}$ & $\mathbf{4 . 4 9 0}$ & \\
\hline
\end{tabular}

Lul, Luleälven; Ume, Umeälven; Dal, Dalälven; Mör, Mörrumsån; Koch, Kochovka.Asterisks refer to significance levels after sequential Bonferroni corrections. *** $P<0.001 ; * * P<0.01$.
Mhc loci often have an extremely large number of alleles with strikingly even allele distributions (Klein, $1990)$. We found seven to 16 alleles in each population and 24 alleles across all populations. The variation in number of identified alleles between populations is probably caused in part by variation in population sizes, as well as by our sample sizes. The fact that the same allele $(B)$ is predominant in three of the four populations suggests that this allele has a selective advantage in resistance against a prevalent pathogen. The much higher frequency of the $B$ allele in Umeälven may indicate that this pathogen has been more prevalent recently in Umeälven than in Dalälven and Luleälven and absent in Mörrumsån. Dalälven, Mörrumsån and the Kochovka River had similar allele distributions with two alleles with frequencies of more than 0.10 (see Appendix). Umeälven had fewer alleles and was more homogeneous in the allele distribution than any of the other populations, whereas Luleälven had the most even allele distribution (see Appendix). During at least five years (1969-1973), a considerable part of the released juveniles in Luleälven originated from other rivers (mainly Skellefteälven and Ångermanälven, Nyman \& Norman, 1987). The introduction of genes from the other populations appears to have had a larger effect on allele frequencies, than on number of alleles.

In several human populations (Hedrick \& Thomson, 1983) and some galliform birds (von Schantz et al., 1996; M. Grahn, T. S. Johansen, W. K. Potts and M. Zuk, unpubl. obs.), observed heterozygosity exceeds that expected at several $M h c$ loci. In contrast, in Atlantic salmon we found no difference between observed $\left(H_{\mathrm{I} i}\right)$ and expected $\left(H_{\mathrm{S} i}\right)$ heterozygosity (Table 1$)$. The reason for this is probably that total random mating is performed in the hatcheries and that we sampled juveniles that had not been exposed to selection $(<4$ months after hatching). However, there tended to be a deficiency of homozygous individuals in the broods that had survived M74 (Table 1) indicating that natural selection may favour heterozygous individuals.

The results of the present study indicate that a difference in the average effective population size between 116 (Dalälven) and 394 (Luleälven, Table 1) does not have as large effect on the level of Mhc heterozygosity as a difference between 68 (Umeälven) and 116 (Dalälven, Table 1). Using a constantly low number of individuals $\left(N_{\mathrm{e}}<100\right)$ thus appears to reduce $M h c$ heterozygosity and allelic diversity as well as cause a loss of Mhc alleles. These data support the theoretical results obtained by Waples (1990) that 100 breeders per year would be

(C) The Genetical Society of Great Britain, Heredity, 80, 568-575. 
sufficient to preserve most alleles in a population. Even though there is selection for maintaining large variation in the $M h c$, repeated genetic bottlenecks will increase the risk of loss of rare alleles. In some mammal populations, outbreaks of severe diseases have been explained as a consequence of decreased Mhc variation caused by genetic bottlenecks (O'Brien \& Evermann, 1988). Also, in Atlantic salmon, incidences of genetic bottlenecks appear to decrease the degree of $M h c$ variation. The two populations with the lowest $M h c$ variation (Umeälven and Mörrumsån) have been exposed to repeated genetic bottlenecks $(<60$ breeders per year, Table 1), whereas more than 60 breeders have been used in all years in the two populations with higher $M h c$ variation. If the low heterozygosity observed in Umeälven results from inbreeding and genetic drift, this river runs the largest risk of inbreeding depression in terms of diseases among the studied populations. Interestingly, there has been much higher incidence of M74 in Umeälven than in Luleälven and Dalälven. Mörrumsån had an intermediate level of $M h c$ heterozygosity despite the lowest average $N_{\mathrm{e}}$ and exposure to repeated genetic bottlenecks. This may be explained by the fact that salmon reproduce naturally in this river and that these, together with the salmon produced in the hatcheries should be regarded as one single population and thus have an actual $N_{\mathrm{e}}$ that is larger than our estimate.

Salmonid populations often show differentiation between and within drainages with genetic distances ranging from 0.001 to 0.052 , measured in studies using enzyme electrophoresis (Guyomard, 1981; Ståhl, 1981; Guyomard \& Krieg, 1983). The genetic distances between the four populations in this study were between 0.085 and infinity (Table 3 ). However, it should be recognized that variation in enzyme coding loci is not directly comparable to variation in Mhc loci because of large differences in the degree of neutrality and polymorphism. The high values of Nei's $D$ in this study (Table 3 ) may be explained mainly by the large number of alleles and the high degree of heterozygosity per se, and that $M h c$ is affected by selection (i.e. it is not a neutral marker). In addition, our results indicate that the natural selection pressures vary between different populations.

Under neutrality, the geographically closest populations are expected to have the shortest genetic distance (Hartl \& Clarke, 1989). We therefore expected the smallest genetic distance to be between Luleälven and Umeälven. However, the genetic distance between these two rivers is higher than that between Dalälven and Umeälven, and that between
Dalälven and Luleälven (Table 3). This pattern of strong differentiation between the populations is further observed in the pairwise $F_{\mathrm{ST}}$ values [all being highly significant apart from the one between Luleälven and Dalälven (Table 3)] and in the highly significant overall $F_{\text {ST }}$ value (0.13). Another factor influencing the genetic distance and hence the degree of differentiation is gene flow, which is considered to be low in natural salmon populations (Taylor, 1991). However, as mentioned above, transplantations of salmon have been performed into the River Luleälven from a number of other rivers (Nyman \& Norman, 1987). Hence, increased rates of gene flow from Dalälven (or a nearby population) to Luleälven because of artificial transplantation may possibly explain the low genetic distance.

Our results indicate that using low numbers of breeders in salmon hatcheries leads to decreased heterozygosity levels and loss of alleles in $M h c$ genes, which may have important implications for disease resistance. It is therefore interesting to note that in the present study, the two hatchery populations with the lowest $M h c$ heterozygosity (Umeälven and Mörrumsån) had the highest rates of the fatal syndrome M74.

\section{Acknow ledgements}

We are very grateful to H. Börjesson, H. Johansson, K. Johansson and R. Ericsson, for providing us with the samples. T. Säll and T. Kraft gave supporting advice on the statistics. K. Persson did much of the laboratory work. S. Bensch, S. Edwards, D. Hasselquist and P. Hedrick gave valuable comments on earlier drafts of this paper. $\varnothing$. Lie and U. Grimholt kindly provided us with the probe Sasa II. This work was financially supported by the Swedish Council for Forestry and Agricultural Research (SJFR), the Swedish Council for Planning and Co-ordination of Research (FRN), the Swedish Environmental Protection Agency (SNV), The Swedish Polar Research Secretariat and Carl Tesdorpf's foundation.

\section{References}

ALLENDORF, F. W. AND PHELPS, S. R. 1980. Loss of genetic variation in a hatchery population of cutthroat trout. Trans. Am. Fish. Soc., 109, 537-543.

AMCOFF, P., NORRGREN, L., BÖRJESSON, H. AND LINDEBERG, J. 1995. Lowered concentrations of thiamine (Vitamin $\mathrm{B}_{1}$ ) in M74-affected feral Baltic salmon (Salmo salar). In: Bengtsson, B-E., Hill, C. and Nellbring, S. (eds) Report from the Second Workshop on Reproduction 
Disturbances in Fish, 20-23 November 1995, pp. 38-39. Swedish Environmental Protection Agency, report 4534.

BENGTSSON, B.-E., BERGMAN, A., BRANDT, I., HILL, C., JOHANSSON, N., SÖDERGREN, A. ET AL. 1994. Reproductive Disturbances in Baltic Fish. Research programme for 1994/95-1998/99. Swedish Environmental Protection Agency, report 4319 (in Swedish).

BERNATCHEZ, L., GUYOMARD, R. AND BONHOMME, F. 1992. DNA sequence variation of the mitochondrial control region among geographically and morphologically remote European brown trout Salmo trutta populations. Mol. Ecol., 1, 161-173.

ELLEGREN, H., HARTMAN, G., JOHANSSON, M. AND ANDERSSON, L. 1994. Major histocompatibility complex monomorphism and low levels of DNA fingerprinting variability in a reintroduced and rapidly expanding population of beavers. Proc. Natl. Acad. Sci. U.S.A., 90, $8150-8153$.

ERIKSSON, T. AND ERIKSSON, L.-O. 1993. The status of wild and hatchery propagated Swedish salmon stocks after 40 years of hatchery releases in the Baltic rivers. Fish. Res., 18, 147-159.

GRIMHOLT, U., OLSAKER, I., DE VRIES LINDSTRøM, C. AND LIE, Ø. 1994. A study of variability in the MHC class II $\beta 1$ and class I $\alpha 2$ domain exons of Atlantic salmon, Salmo salar L. Anim. Genet., 25, 147-153.

GUYOMARD, R. 1981. Electrophoretic variation in four French populations of domesticated rainbow trout (Salmo gairdineri). Can. J. Genet. Cytol., 23, 33-47.

GUYOMARD, R. AND KRIEG, F. 1983. Electrophoretic variation in six populations of brown trout (Salmo trutta L.). Can. J. Genet. Cytol., 25, 403-413.

HARDEE, J. J., GODWIN, U., BENEDETTO, R. AND MCCONNELL, т. J. 1995. Major histocompatibility complex II A gene polymorphism in the striped bass. Immunogenetics, 41, 229-238.

Hartl, D. L. AND Clark, A. G. 1989. Principles of Population Genetics, 2nd edn. Sinauer, Sunderland, MA.

HEDRICK, P. w. 1985. Genetics of Populations. Jones and Bartlett Publishers, Boston, MA.

HEDRICK, P. W. AND THOMSON, G. 1983. Evidence for balancing selection at HLA. Genetics, 104, 449-456.

HORDVIK, I., GRIMHOLT, U., FOSSE, V. M., LIE, Ø. AND ENDRESEN, C. 1993. Cloning and sequence analysis of cDNAs encoding the MHC II $\beta$ chain in Atlantic salmon (Salmo salar). Immunogenetics, 37, 437-441.

HUGHeS, A. L. AND NEI, M. 1988. Pattern of nucleotide substitution at major histocompatibility complex class I loci reveals overdominant selection. Nature, 335, 167-170.

KLEIN, J. 1990. Immunology. Blackwell Scientific Publications, Boston, MA.

Lignell, A. 1995. Astaxanthin in yolk-sac fry from feral Baltic salmon. In: Bengtsson, B.-E., Hill, C. and Nellbr- ing, S. (eds) Report from the Second Workshop on Reproduction Disturbances in Fish, 20-23 November 1995, pp. 94-96. Swedish Environmental Protection Agency, report 4534 .

MIKKO, S. AND ANDERSSON, L. 1995. Extensive MHC class II DRB3 diversity in African and European cattle. Immunogenetics, 42, 408-413.

MILLER, N. W., RYCYZYN, M. A., WILSON, M. R., LUFT, J. C., Stuge, T. B., VAllejo, A. N. ET AL. 1993. The use of long term leukocyte lines for studying the immune response of fish (Abstract). The Nordic Symposium on Fish Immunology. 19-22 May, 1993. Lysekil, Sweden.

NEI, M. 1977. F-statistics and analysis of gene-diversity in subdivided populations. Ann. Hum. Genet., 41, 225-233.

NEI, M. 1978. Estimation of average heterozygosity and genetic distance from a small number of individuals. Genetics, 89, 583-590.

NiZetic, D., FigueroA, F., NEVo, E. AND KLein, J. 1985. Major histocompatibility complex of the mole rat II. Restriction Fragment Length Polymorphism. Immunogenetics, 22, 55-67.

NYMAN, L. AND NORMAN, L. 1987. Genetiska aspekter på odling av lax och havsöring för utplantering: Riktlinjer för avelsmetodik och fiskevård. Laxforskninginstitutet meddelande 1987: 4 (in Swedish, abstract in English).

O'BRIEN, S. J. AND EVERMANN, J. F. 1988. Interactive influence of infectious disease and genetic diversity in natural populations. Trends Ecol. Evol., 3, 254-259.

RICE, w. R. 1989. Analyzing tables of statistical tests. Evolution, 43, 223-225.

RYMAN, N. AND STÅHL, G. 1980. Genetic changes in hatchery stocks of brown trout (Salmo trutta). Can. J. Fish. Aquat. Sci., 47, 82-87.

STÅHL, G. 1981. Genetic differentiation among natural populations of Atlantic salmon (Salmo salar) in northern Sweden. In: Ryman, N. (ed.) Fish Gene Pool. Ecol. Bull. (Stockholm), 34, 95-105.

TAYLOR, E. B. 1991. A review of local adaptation in salmonidae, with particular reference to Pacific and Atlantic salmon. Aquaculture, 98, 185-207.

TESSIER, N., BERNATCHEZ, L., PRESA, P. AND ANGERS, B. 1995. Gene diversity analysis of mitochondrial DNA, microsatellites and allozymes in landlocked Atlantic salmon. J. Fish Biol., 47 (Suppl. A), 156-163.

VON SCHANTZ, T., WITTZELL, H., GÖRANSSON, G., GRAHN, M. AND PERSSON, K. 1996. MHC genotype and male ornamentation: genetic evidence for the Hamilton-Zuk model. Proc. R. Soc. B., 263, 265-271.

WAPLES, R. S. 1990. Conservation genetics of Pacific salmon. II. Effective population size and the rate of loss of genetic variability. J. Hered., 81, 267-276.

WEIR, B. S. AND COCKERHAM, C. C. 1984. Estimating $F$-statistics for the analysis of population structure. Evolution, 38, 1358-1370. 
Appendix Frequencies of the variant RFLP alleles in Mhc class II $\beta$ and the result of Fisher's exact test for homogeneity $(P)$ in the four Baltic Sea populations of Atlantic salmon, and allele frequencies from Kochovka River. Figures in parentheses refer to allele frequencies in broods that survived the syndrome M74

\begin{tabular}{|c|c|c|c|c|c|c|}
\hline \multirow[b]{2}{*}{ Allele } & \multicolumn{4}{|c|}{ Population } & \multirow[b]{2}{*}{$P^{1}$} & \multirow[b]{2}{*}{ Kochovka } \\
\hline & Luleälven & Umeälven & Dalälven & Mörrumsån & & \\
\hline$A$ & $0.01(0.02)$ & $0.08(0.10)$ & $0.01(0)$ & $0(0)$ & 0.138 & 0 \\
\hline$B$ & $0.33(0.32)$ & $0.69(0.65)$ & $0.35(0.41)$ & $0(0)$ & $2.06 \times 10^{-9 * * *}$ & 0 \\
\hline$C$ & $0.11(0.13)$ & $0.06(0)$ & $0.02(0.03)$ & $0(0)$ & 0.156 & 0.48 \\
\hline$D$ & $0.21(0.20)$ & $0.04(0.10)$ & $0.09(0.06)$ & $0(0)$ & 0.004 & 0 \\
\hline$E$ & $0.14(0.15)$ & $0.02(0.05)$ & $0.21(0.25)$ & $0(0)$ & $8.32 \times 10^{-4 *}$ & 0.1 \\
\hline$F$ & $0(0)$ & $0.04(0)$ & $0.04(0)$ & $0(0)$ & 0.301 & 0 \\
\hline$G$ & $0.04(0.02)$ & $0.02(0.05)$ & $0.06(0.09)$ & $0(0)$ & 0.566 & 0.04 \\
\hline$H$ & $0.03(0.04)$ & $0(0)$ & $0.04(0.03)$ & $0.08(0)$ & 0.016 & 0 \\
\hline I & $0.01(0.02)$ & $0(0)$ & $0.05(0.03)$ & $0(0)$ & 0.347 & 0 \\
\hline$K$ & $0.03(0.04)$ & $0.06(0.05)$ & $0.01(0.03)$ & $0(0)$ & 0.416 & 0.02 \\
\hline$L$ & $0.01(0.02)$ & $0(0)$ & $0.02(0.06)$ & $0.15(0.33)$ & 0.161 & 0 \\
\hline$M$ & $0(0)$ & $0(0)$ & $0.02(0)$ & $0(0)$ & 0.481 & 0 \\
\hline$N$ & $0(0)$ & $0(0)$ & $0.01(0)$ & $0(0)$ & 1.000 & 0 \\
\hline$O$ & $0(0)$ & $0(0)$ & $0.01(0)$ & $0(0)$ & 1.000 & 0 \\
\hline$P$ & $0(0)$ & $0(0)$ & $0.01(0)$ & $0(0)$ & 1.000 & 0 \\
\hline$Q$ & $0(0)$ & $0(0)$ & $0.04(0)$ & $0.58(0.50)$ & $4.75 \times 10^{-15 * * *}$ & 0 \\
\hline$\widetilde{R}$ & $0(0)$ & $0(0)$ & $0(0)$ & $0.04(0)$ & 0.112 & 0 \\
\hline$S$ & $0(0)$ & $0(0)$ & $0(0)$ & $0.04(0)$ & 0.112 & 0.1 \\
\hline$T$ & $0.01(0.02)$ & $0(0)$ & $0(0)$ & $0.04(0)$ & 0.182 & 0 \\
\hline$U$ & $0.01(0.02)$ & $0(0)$ & $0(0)$ & $0.04(0)$ & 0.182 & 0 \\
\hline$V$ & $0(0)$ & $0(0)$ & $0(0)$ & $0.04(0.17)$ & 0.112 & 0 \\
\hline$W$ & $0(0)$ & $0(0)$ & $0(0)$ & $0(0)$ & & 0.24 \\
\hline$X$ & $0.01(0)$ & $0(0)$ & $0(0)$ & $0(0)$ & 0.647 & 0.02 \\
\hline Y & $0.03(0.02)$ & $0(0)$ & $0(0)$ & $0(0)$ & 0.357 & 0 \\
\hline No. zygotes & $\begin{array}{l}72 \\
(54)\end{array}$ & $\begin{array}{l}52 \\
(20)\end{array}$ & $\begin{array}{l}82 \\
(32)\end{array}$ & $\begin{array}{l}26 \\
(6)\end{array}$ & & 50 \\
\hline
\end{tabular}

${ }^{1}$ Asterisks refer to significance levels after sequential Bonferroni corrections (Rice, 1989); allele: $Q,{ }^{* *} P<0.001 / 23=0.00004 ; B,{ }^{* * *} P<0.001 / 22=0.00005 ; E,{ }^{*} P<0.05 / 21=0.002$. 